\title{
Learning and Teaching Model on Covid 19 Era at UIN Maulana Malik Ibrahim Malang Indonesia
}

\author{
Triyo Supriyatno \\ Universitas Islam Negeri Maulana Malik Ibrahim Malang, Indonesia \\ triyo@pai.uin-malang,ac.id
}

\begin{abstract}
In practice, the implementation of the teaching and learning process is less encouraging on achieving critical thinking skills. In this Era of the 4.0 industry revolution, technology-based learning innovations are needed. Revitalizing learning systems, new literacy movements, digital literacy, technological literacy, human literacy become a necessity as the breadth and deepening of learning materials are capable of information technology. Technology in the educational world has created a huge influence, one of the learning models needed by the E-Learning Model. ELearning is an application with Internet access that can connect between educators and students in an online study room. The purpose of this research is to know the E-Learning model of learning in improving students 'critical thinking. The method used in this study is qualitative research using a descriptive method. The type of case study with one site design. Research results show the ELearning model can encourage students to think critically on the subject's material.
\end{abstract}

Keywords: learning Model E-Learning, critical thinking

This is an open access article under the CC-BY-NC license.

\section{INTRODUCTION}

Two factors that cause the existence of critical thinking do not develop during education, the curriculum is generally designed with broad material targets so that the teacher is more focused on completing the material and the teacher's lack of understanding of learning methods that can improve critical thinking skills.

The problem is, can critical thinking be trained? According to experts, practicing critical thinking can be done by questioning what is seen and heard. After that, proceed with asking why and how about it. In essence, do not immediately accept the raw incoming information. Wherever it comes, the information obtained must be digested properly and carefully before finally being concluded. Therefore, practicing critical thinking also means to behave cautiously and not to rush in dealing with problems.

There are other views to improve critical attitude. According to research by neuro linguists, a branch of science that studies language and nerve functions, the human brain can be trained in its functions, including giving birth to critical attitudes. According to them, the human brain is divided into two, namely the left brain that produces verbal, imitative and repetitive language, and the right 
brain which produces thoughts that are imaginative, comprehensive, and contemplative. It is suspected that the great people who made a great history were people who had active right brains.

\section{LITERATURE REVIEW}

\section{1 "Where" and "When" to teach and learn}

There are several ways to brand e-education in the use of the terms "where" so "when" (Allen and Seaman, 2014; Gaebel et al., 2014b; Means et al., 2010). Trendy this case we make known to important footings like e-education, merged or learning by hybrid, connected education, and by what means these perceptions can be understood. The primary step strength is situated to discover by what means these footings can be applied to "where" and "when" concerning the elasticity of advanced instruction.

\subsection{Classification of Learning by Online}

United States Department of Academic reviewed and analyzed online classes as "Classes that happens partly or fully through the internet (Means et al.,2010, p. 9). Online classes being promoted with the reasoning to substitute vis a vis learning. Online classes combined with face to face instruction to give improvement toward lessons. (Means et al., 2010). We discover a similar approach in the American online classes survey, which done every year since 2006 by the Babson Survey Group (Allen and Seaman, 2014). In this survey 4 categories in regards to internet usage in many classes. Also, where and when appear to be an indicator. The first category includes traditional classes, in which the internet is not used. In the second category, the internet supports the traditional vis a vis class, by posting syllabus in the study management platform for example. The third category includes hybrid data in which sending big online content and video tutorial through the internet. The last category includes classes that are being held fully or mostly online. (Allen and Seaman, 2014, p. 6). E-learning is used to identify classes that are supported by information technology. Where and when variations are linked to blended learning and online classes. (Gaebel et al., 2014b). Table 19.1 shows how the approach where and when are linked to IT-based teaching.

Table 1. e-Learning suitable "Where" and "When"

\begin{tabular}{|c|c|c|c|c|c|}
\hline \multirow{3}{*}{ 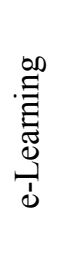 } & \multicolumn{3}{|c|}{ "Where" } & \multicolumn{2}{|c|}{ "When" } \\
\hline & & $\begin{array}{c}\text { UIN based } \\
\text { (classroom) }\end{array}$ & $\begin{array}{r}\text { Distance } \\
\text { (Wherever) }\end{array}$ & $\begin{array}{l}\text { Synchronous } \\
\text { (real-time) }\end{array}$ & $\begin{array}{l}\text { Asynchronous } \\
\text { (Whenever) }\end{array}$ \\
\hline & $\begin{array}{l}\text { Blended } \\
\text { Online } \\
\text { MOOCs }\end{array}$ & $\mathrm{X}$ & $\begin{array}{l}X \\
X \\
X\end{array}$ & $\begin{array}{l}X \\
X\end{array}$ & $\begin{array}{l}X \\
X \\
X\end{array}$ \\
\hline
\end{tabular}

Over the years in electronic learning at IPT there have been changes in the absorption of the terms 'where' and 'when'. For illustration, Bates (2014) circumstances that e-learning actions have reformed from existence a complement to out-of-date learning, it is so distinct by way of combined knowledge, to the habit of tutorial room replicas, wherever learning actions move from the teaching space to the Cyberspace, to come again it features as' classroom re-planning based on "campus" where campus teaching is reconsidered, because of the habit of knowledge "(Bates, 2014). He described this advance as touching as of being 'where and' when 'to a result, such as a vis interface on virtual site or in the classroom, to elastic explanations, as well as connected knowledge from a reserve. Elasticity includes scholars and instructors (Bates, 2014).

Research Bacow (et al.: 2012) suggest distinguishing the 4 halberds from which satisfied and approaches are grouped in connected knowledge to comprehend forms of range. These halberds are: 
(1) a purely online approach versus a mixture so includes vis a vis interface; (2) an independent system compared to a system in which wholly scholars participate simultaneously in teaching and learning in a set schedule; (3) the systems that depend on public competitions and friend-grounded approaches to arrangements that are concerned with individual learners; so (4) large exposed connected paths (MOOCs), namely comprehensive learning shaped by ironware, as opposed to methods that involve substantial ways by instruction teams to confirm interface with scholars.

\section{RESEARCH METHODOLOGY}

This study using a qualitative approach with the following characteristics; 1) takes place in a scientific setting, 2) the researcher becomes the main instrument or data collection tool, and 3) the data analysis is carried out inductively. Through a qualitative approach, this study seeks to provide explanatory, rational answers, focusing on the question of "how", which is structured in the design of research as a scientific responsibility. By always linking the logical relationship between questions asked, collecting relevant data, and analyzing research results.

The steps in this study are as follows: 1) Collecting data on the moral learning paradigm as a theoretical foundation, 2) Collecting data on moral learning to form moderate Muslims, 3) Analyzing to obtain an abstraction about moral learning strategies and strategies for the formation of moderate Muslims. In data analysis, modified analysis is a way to develop theories and test them (Robert, 1998: 65).

The characteristics of this study, carried out using multi-site studies (multi-site studies), which is a qualitative research design involving several sites with research subjects that are assumed to have the same characteristics. As explained by Bogdan and Biklen (1998: 98), the multi-site study design is one form of qualitative research design, which can be used primarily to develop theories that are raised from several similar research settings, so that theories can be generated that can be transferred to more situations broad and more general scope.

Data collection techniques used in this study were interviews, observation, and documentation. Interviews are used to capture data or information relating to strategies used in internalizing religious moral values. Observation is used to obtain data regarding the implementation of the methods used in internalizing religious moral values in the learning process. Documentation is used to obtain data about the description of the object under study. Also, to complete the data from interviews and observations.

To get data that can be scientifically justified, from the data that has been collected, check the validity first. In this research, the technique of checking the validity of the data used is the triangulation technique, which is the crossing of information obtained from the source so that in the end only valid data is used to achieve the results of the study (Arikunto, 2006: 18).

The triangulation technique used in this study is the triangulation of methods and sources, namely by reconfirming the interview information with documentation and observation. Research data obtained from different sources through interviews were reconfirmed with data obtained through observation and documentation. The data used in this study are valid data after going through the process of crossing information. The data analysis technique used in this study is the inductive analysis technique, which is an analysis that departs from the data and leads to general conclusions.

\section{FINDING AND DISCUSSION}

In the learning process of students of course the teacher has an important role to participate in shaping the character of students who are critical in dealing with various situations. The ability to think critically, of course, cannot be obtained instantly but must be familiarized and well implanted. 
Various ways can be done to build critical thinking habits for students, especially junior high-class students who will face the next world.

Critical thinking itself according to experts has a level of importance that is almost the same as writing and reading as academic competencies. So by definition, critical thinking is an interpretation and evaluation in observing, capturing information, communicating, and actively arguing. Of course, this is one of the reasons why it is important to have the ability to think critically.

Teachers need to provide learning techniques for students whose focal point is to develop critical thinking skills. That way there will be various advantages that can be obtained as follows: Helps to increase student and teacher enthusiasm during the learning process. By getting students to think critically then whatever is learned will stick to students' minds longer, to achieve optimal learning goals Students will be trained to have the ability to solve problems that begin when studying at class and then get used to doing it with various challenges of life outside the class environment. That way the information obtained will be more in-depth and comprehensive as knowledge for students. These benefits can be obtained if the teachers can maximize how to make students able to think critically. The activity of each child to optimize his critical attitude is indeed different, but of course, it can be trained so that it continues to grow and become an ability that can be used by students in life in society and face various types of challenges or problems.

Students must continue to try to find the latest sources of information to be used as consideration in thinking. Students must also be accustomed to having an open attitude towards the statements of others as well as new information that comes in without ignoring the initial consideration that has been done. So that later this ability can be applied to solve a problem or challenge.

After having the ability to think critically, the teacher has the next important pran. The role is to remind and encourage students' sensitivity to the feelings of others, different ways of thinking, and perhaps the complexity of the thoughts possessed by others and the interlocutors. That way even though his way of thinking is critical but not to hurt others who might think differently from one another. 


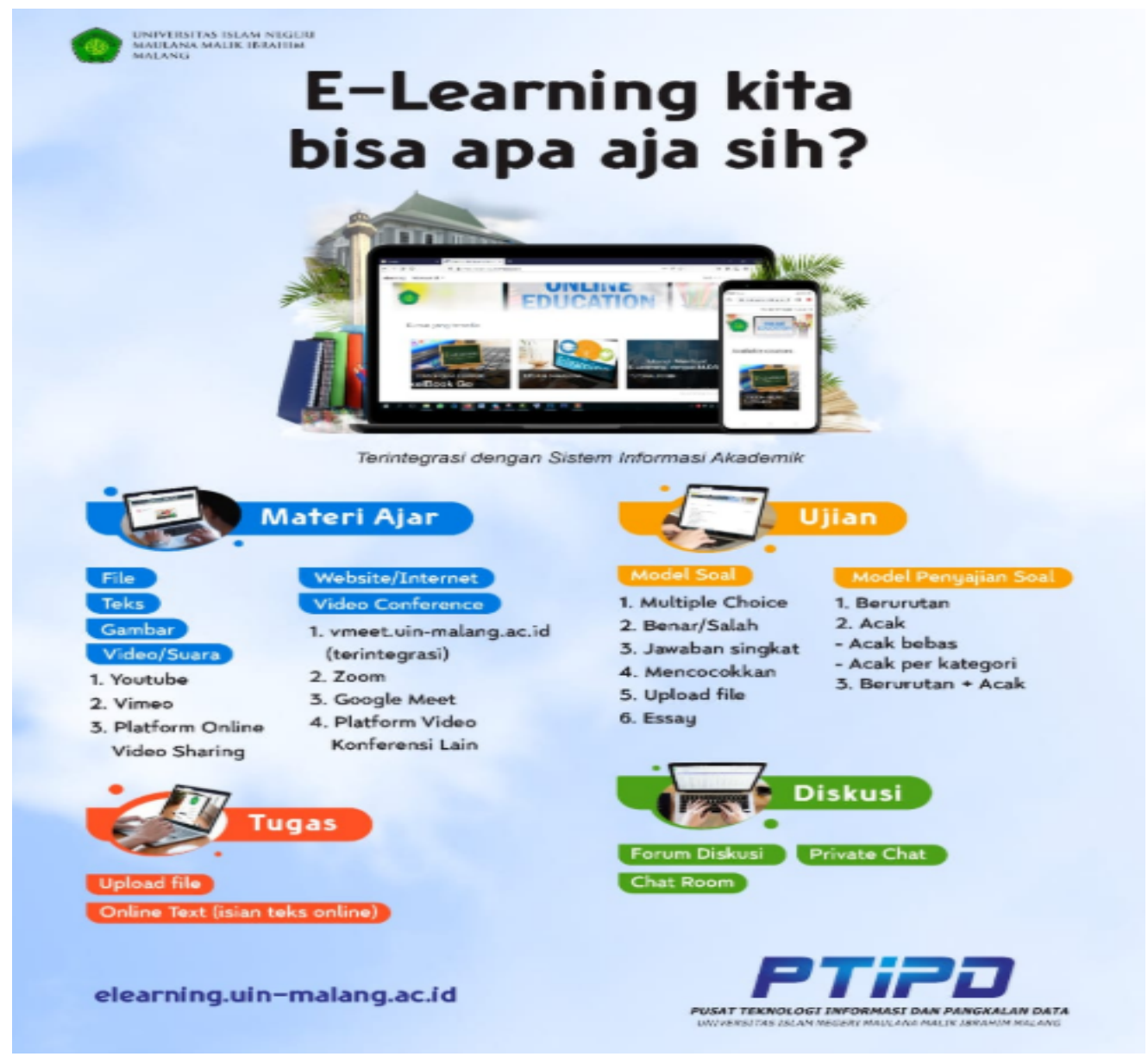

Figure 1. E-Learning Model on UIN Maulana Malik Ibrahim Malang

\section{CONCLUSION AND FURTHER RESEARCH}

E-Learning Learning Model can encourage students to think critically about the subject matter. The combination of various strategies in more recommended because it can achieve various aspects of the critical thinking component. Teaching technology that applies a combination of various existing strategies such as the E-Learning Learning Model. Educators need to develop these teaching strategies in teaching so that students can learn historical learning material through the process of critical thinking. Thus students can give a deeper meaning (not just get deep material) from the material being studied. Critical thinking in the process of learning this history can be accomplished if all the facts about historical events can be found, using the teacher and students having complete sources and materials.

\section{REFERENCES}

Allen, I. E., and J. Seaman (2014) Grade Change. Tracking Online Education in the United States (Wellesley, MA: Babson College/Sloan Foundation)

Bacow, L. S., Bowen, W. G., Guthrie, K. M., Lack, K. A. and M. P. Long (2012) Barriers to Adoption of Online Learning Systems in U.S. Higher Education. Retrieved from 
http://www.sr.ithaka.org/sites/default/files/reports/barriers-to-adoption-of-onlinelearning-systems-in-us-higher-education.pdf. Baggaley, J. (2013) 'MOOC rampant', Distance Education, 34(3), 368-378.

Bates, T. (2014) Teaching in a Digital Age. Open Textbook. Retrieved from http://opentextbc.ca/teachinginadigitalage/

Dewi, E. K., \& Jatiningsih, O. (2015). Pengaruh Penggunaan Model Pembelajaran Problem Based Learning Terhadap Kemampuan Berpikir Kritis Siswa Pada Mata Pelajaran PPKn Kelas X Di SMAN 22 Surabaya. Kajian Moral Dan Kewarganegaraan, 2(3), 936-950.

Gaebel, M., Kupriyanova, V., Morais, R. and E. Colucci (2014) E-learning in European Higher Education Institutions: Results of a Mapping Survey Conducted in October-December 2013 (Brussels: European University Association).

Insyasiska, D., Zubaidah, S., \& Susilo, H. (2017). Pengaruh project-based learning terhadap motivasi belajar, kreativitas, kemampuan berpikir kritis, dan kemampuan kognitif siswa pada pembelajaran biologi. Jurnal Pendidikan Biologi, 7(1), 9-21.

Means, B., Toyama, Y., Murphy, R., Bakia, M. and K. Jones (2010) Evaluation of EvidenceBased Practices in Online Learning: A Meta-Analysis and Review of Online Learning Studies (Washington, DC: U.S. Department of Education. Office of Planning, Evaluation, and Policy Development Policy and Program Student Service).

Suarsana, I. M. (2013). Pengembangan e-modul berorientasi pemecahan masalah untuk meningkatkan keterampilan berpikir kritis mahasiswa. JPI (Jurnal Pendidikan Indonesia), 2(2).

Setyorini, U., Sukiswo, S. E., \& Subali, B. (2011). Penerapan model problem based learning untuk meningkatkan kemampuan berpikir kritis siswa SMP. Jurnal Pendidikan Fisika Indonesia, $7(1)$.

Belth, Marc.(1977) The Process Of Thinking.New York: David Mc Kay Company

Costa, Arthur L.,(ed.) (1985) Developing Minds, A Resource Book for Teaching Thinking. Virginia: ASCD

Lickona, Thomas. (1991). Educating for character - How our classs can teach respect and responsibility. New York: Bantam Books.

Hilmy, Masdar. (2012). "Menjadi Islam Indonesia", Kompas, 24 Nopember.

Muhadjir, Noeng (2003). Ilmu pendidikan dan perubahan sosial. Yogyakarta: Rake Sarasin.

Robert, C. Bogdan \& Sari, K. Biklen. (1998). Quality Research for Education: An Introduction to Theory and Methods (Boston: Allyn and Bacon, tt.), p. 2.

De Bono, Edward. (1990). Berpikir Lateral, alih Bahasa oleh Budi. Jakarta: Binarupa Aksara.

Didin Wahidin. Makalah disajikan dalam seminar mahasiswa FKIP Uninus 18 Juni 1998.

Dirmawa,Dikti.(1996).Buku Peserta Pelatihan Pembimbing Kelompok Diskusi Mahasiswa (OPPEKTIPE B). Dikti Jakarta.

Gega, Peter C., (1977) Science in elementary education. New York : John Wiley And Sons Inc.

Mestika Zed. 2003. Metodologi Sejarah. Padang: Fakultas Ilmu-ilmu Sosial UNP

Nickerson, Raymond S., (1985) The Teaching Of Thinking. New Jersey: Lawrence Erlbaum

Raths, Louis E., et.al. (1986) Teaching for thinking (2'nd ed.). New York: Teacher College Columbia University.

Sudaryanto, Kajian Kritis tentang Permasalahan Sekitar Pembelajaran Kemampuan Berpikir Kritis Selasa, 26 Agustus 2008 12:50. 